\title{
Racializing the Commonplace Landscape: An Archaeology of Urban Renewal Along the Color Line
}

\author{
Paul R. Mullins \\ 2006 \\ World Archaeology \\ Vol. 38 No. 1 \\ [Author's version. Final published version available from: \\ http://dx.doi.org/ 10.1080/00438240500509884]
}

\begin{abstract}
In the 1960's Indianapolis, Indiana's near-Westside was transformed by urban renewal projects that carved space for the Indiana University-Purdue University Indianapolis (IUPUI) campus out of a predominately African-American neighborhood. Within two decades that longstanding community was totally displaced, and today the former neighborhood covering 300 acres is completely effaced and the community is largely forgotten. This paper examines how archaeology on the University campus provides a mechanism to illuminate the processes that remade the near-Westside. Archaeological research conducted along with the displaced community and its descendants provides a powerful tool to rethink the otherwise prosaic campus landscape as a space shaped by racial and class privilege.
\end{abstract}

\section{Acknowledgements}

Thanks to Greg Mobley and the IUPUI University Archives staff for sharing their research on campus parking. Daisy Borel, Chris Glidden, and my colleagues in the IUPUI Anthropology Department all shaped various pieces of this paper. None of them bear any responsibility for its shortcomings.

Author's version. Final version published as:

Mullins, P.R. (2006). Racializing the commonplace landscape: An archaeology of urban renewal along the color line. World Archaeology, 38(1), 60-71. http://dx.doi.org/ 10.1080/00438240500509884 
Racializing the Commonplace Landscape: An Archaeology of Urban Renewal Along the Color Line

Paul R. Mullins

Indiana University-Purdue University, Indianapolis

In the 1960's Indianapolis, Indiana's near-Westside was transformed by urban renewal projects that carved space for the Indiana University-Purdue University Indianapolis (IUPUI) campus out of a predominately African-American neighborhood. Within two decades that longstanding community was totally displaced, and today the former neighborhood covering 300 acres is completely effaced and the community is largely forgotten. This paper examines how archaeology on the University campus provides a mechanism to illuminate the processes that remade the near-Westside. Archaeological research conducted along with the displaced community and its descendants provides a powerful tool to rethink the otherwise prosaic campus landscape as a space shaped by racial and class privilege.

In 1967 Indianapolis News columnist Bill Roberts surveyed the impact of urban renewal projects that were transforming the Indiana capital's near-Westside. By then the near-Westside had been a densely settled residential neighborhood for over a century, but it was quickly being uprooted for the expansion of the Indiana University Medical Center. Roberts understood that "a whole neighborhood is vanishing," but he was startled that so much of the neighborhood displacement was simply intended to create

Author's version. Final version published as:

Mullins, P.R. (2006). Racializing the commonplace landscape: An archaeology of urban renewal along the color line. World Archaeology, 38(1), 60-71. http://dx.doi.org/ 10.1080/00438240500509884 
parking lots: "Seeing all of the parking areas crowded with cars, you realize there can never be such a thing as too much parking" (Roberts 1967:38).

Two years after Roberts' article, the Indiana University Medical Center became part of Indiana University-Purdue University, Indianapolis (IUPUI), and the newly created University expanded still further into the predominately African-American neighborhood surrounding the campus. Ringed by a sizable African-American community, the mushrooming campus landscape instantly became linked to neighborhood stereotypes. In April 1970, for instance, a student wrote to complain about the arduous trek from his car to the new campus classrooms, arguing that "if the University chooses one of the highest crime-rate districts in the city as its location then they should accept the responsibility of the safety of its students ... One murder, rape or molesting will make the beautiful campus a cancerous breeding ground for fear and panic" (Onomatopoeia April $27,1970: 4)$

The community that inspired apprehension from this 1970 letter-writer is today completely displaced, and very few members of the campus community know much if anything about the neighborhood that occupied campus just three decades ago. Once a space in which state power, student privileges, and neighborhood rights clashed along the color line, today the landscape is a remarkably uncontested sea of parking lots and institutional architecture. The discord over campus parking is superficially mundane and may seem rather disconnected to racism, yet it is symptomatic of how the landscapes of urban renewal have effaced heritage, eluded race, and allowed many people to ignore how their privileges were historically secured along color and class lines.

Author's version. Final version published as:

Mullins, P.R. (2006). Racializing the commonplace landscape: An archaeology of urban renewal along the color line. World Archaeology, 38(1), 60-71. http://dx.doi.org/ 10.1080/00438240500509884 


\section{Archaeology and Race}

In a society whose fundamental rights have always been shaped by race, material culture harbors the contradictions over and tensions within racial discourse, but parking lots and commonplace commodities typically belie such tensions. Since 1999, archaeology in Indianapolis' near-Westside has been conducted to illuminate those contradictions, probe how they were invested in even the most commonplace things, and examine how they rationalized inequality and citizen rights. Our archaeology project defines race as a subjectivity that attempts to disempower particular social groups. This makes race ideological in the sense that it is constructed to serve particular social interests and is typically championed by groups that seem to have something to gain from selectively marginalizing another group. Nevertheless, that makes race no less "real" than (or separable from) dimensions of identity such as class that are rooted in some reasonably objective material difference. Race must have materiality because racial subjectivity is a concrete experience structured by legal and lived reality (Epperson 2004:101).

American racism has most often found its foundation in White supremacy that provides apparent citizen privileges to those subjects classed as White. Consequently, much of an archaeology of race and racism should aspire to identify what Whites secured from particular racial discourses, not simply how Blacks and other marginalized racial subjects were instrumentally disempowered by anti-Black racism. Being White confers what David Roediger (1991) calls a psychological and social "wage" that was especially attractive to working classes who were otherwise marginalized. Being White secures social deference and everyday public rights that were denied to African

Author's version. Final version published as:

Mullins, P.R. (2006). Racializing the commonplace landscape: An archaeology of urban renewal along the color line. World Archaeology, 38(1), 60-71. http://dx.doi.org/ 10.1080/00438240500509884 
Americans. Roediger (1991:177) argues that Whites' reluctance to define freedom in a way that embraced both Blacks and Whites perpetuated anti-Black racism long after Emancipation while it solidified White working-class marginalization.

Relatively little historical archaeology has tackled the impression of racism and the color line beyond conceding racism as a rather ambiguous social process (exceptions include Babson 1990, Davidson 2004, Epperson 1990, Mullins 1999, Orser 2004, Paynter 1990). For many archaeologists, the dilemma has been reduced to methodologically defining what race and racism literally "look like" in the archaeological record and material patterns. However, it is probably somewhat more productive to suggest that an archaeology of the color line has two basic dimensions. First, there is this methodological dimension that frames how we can define race in the material world: That is, what forms does race assume in material consumption patterns? The challenge of "seeing" race is very straightforward in some ways and remarkably complicated in others. It would be difficult to look at American life and not see the color line as the central mechanism structuring American society over better than four centuries. All social privilege in American life has been fundamentally shaped by racial ideology, so race must have a concrete material form. How race is actually materialized in any place or moment is distinctive given the dynamic nature of life along the color line, but race has had some impression on all material life: All material consumption should harbor some measure of racialized symbolism because no social processes are completely disconnected from race and racism.

This is not simply a methodology question, though, because the question is why archaeologists have not considered race a significant dimension of material symbolism,

Author's version. Final version published as:

Mullins, P.R. (2006). Racializing the commonplace landscape: An archaeology of urban renewal along the color line. World Archaeology, 38(1), 60-71. http://dx.doi.org/ 10.1080/00438240500509884 
if not all social life. Consequently, the second dimension of an archaeology of race is that it should illuminate the impression of race and color privilege across time and in the contemporary social and material world: That is, how can archaeology compel us to confront how race has profoundly shaped our lives? What is the connection between everyday material culture, contemporary privilege, and race? This dimension of an archaeology of race is consciously engaged and focused on how archaeology can illuminate the ideological and lived contradictions of life along and across the color line. Race is utterly material and continues to impact peoples' experiences, so race should be both archaeology "testable" and socially relevant. Yet for many American historical archaeologists the material record is fundamentally a reflection of rather stable cultural identities that people brought from various points in Europe and Africa.

In some ways the notion that race is embedded in all material symbolism provides a quite new way of defining the meaning of goods. This contextualization of objects assumes that race is a "backdrop" against which all material meaning is defined. We could look at material consumption patterns among White consumers, for instance, and probe how these consumers are attempting to conform to racial ideology and construct themselves as White. We could do this among any collective and examine how different groups would likely see the same standardized things in particular ways that reflect their distinctive racial positions. This shifts the intellectual question of race away from a mechanical analysis on Black consumers alone and instead positions all consumers along a dynamic racial continuum.

Race has been used to rationalize what social subjects deserve citizen rights, and African Americans have historically been denied basic civil rights through both laws

Author's version. Final version published as:

Mullins, P.R. (2006). Racializing the commonplace landscape: An archaeology of urban renewal along the color line. World Archaeology, 38(1), 60-71. http://dx.doi.org/ 10.1080/00438240500509884 
and informal segregation. Racism has also been used to legitimize public rights that seem completely disconnected to the color line. For instance, in the 1920's a material ideal was projected onto nationalism and defined as "consumer citizenship," but racial ideology assumed that this ideal was inaccessible to African Americans (and most working-class people as well) (cf. Cohen 2003). In Indianapolis many unexamined social privileges emerged from complex and dynamic forms of racist ideology, and as in most of American history the profound impression of racism has been largely ignored. Today the prosaic IUPUI campus and its sea of parking lots exhibit no obvious debt to racist urban renewal programs, which makes it easy to ignore the complicated class and racial conflict played out in the near-Westside. Nevertheless, the landscape clearly was produced by anti-Black racism that aspired to disband a powerful voting block, disperse a longstanding African-American business community, and dispel pockets of poverty within site of the State Capital.

Since 1999 archaeological research in Indianapolis' near-Westside has aspired to illuminate the connection between racism, the urban landscape, and the contemporary IUPUI campus. Archaeology holds very powerful tools to make these connections more visible: Any visitor to a near-Westside archaeological site is literally standing atop stratigraphic deposits that contain household refuse, architectural debris, evidence of the area's complex ecology over millennia, and many layers of fill leveling the contemporary campus. We conduct archaeological research that stresses how these landscapes reflect the complexity of life across and along the color line in Indianapolis.

Author's version. Final version published as:

Mullins, P.R. (2006). Racializing the commonplace landscape: An archaeology of urban renewal along the color line. World Archaeology, 38(1), 60-71. http://dx.doi.org/ 10.1080/00438240500509884 
Our project is conducted in partnership with many former near-Westside residents who grew up in these communities or feel some claim on this history. We conduct oral histories and have African-American elders discuss their lives and communities in classrooms and on archaeological sites as a mechanism to see the campus' history as one of joint stewardship between University and descendant communities. However, the descendant community is the primary voice that defines our research questions and directs long-term archaeological interpretation and preservation (cf. Mack and Blakey 2004), and descendants have a variety of sentiments about how the archaeological questions on African-American experience should be framed. Many of the project's African-American partners see archaeology as a mechanism to document and preserve African-American life in a segregated community, but some are circumspect about how the project should publicly frame this research as an archaeology of race. Elders' interests often revolve around Black entrepreneurship, church life, segregated schools, and the general picture of an ambitious AfricanAmerican middle class. This vision of African-American Indianapolis tends to elevate success stories and aspiration to the heart of community history, but such stories also indirectly defuse racist and class caricatures that have long misrepresented the AfricanAmerican community. Their primary interest in archaeology is not really as an academic mechanism to document race and racism. Instead, descendants see archaeology as a public discourse that reveals and documents African Americans' rich lives in spite of (and perhaps even made possible by) racial segregation. In this sense, they are concerned that we not define race in a way that seems to determine African-American agency or frame all African-American and neighborhood history.

Author's version. Final version published as:

Mullins, P.R. (2006). Racializing the commonplace landscape: An archaeology of urban renewal along the color line. World Archaeology, 38(1), 60-71. http://dx.doi.org/ 10.1080/00438240500509884 
The goal of this sort of engaged archaeology is to examine how life along the color line could so profoundly shape American life while it paradoxically seems invisible to so many people. Why is it that so many IUPUI students and faculty do not see the campus as a racial landscape; why do we fail to recognize that race shaped the way people define commonplace commodities; and how can archaeology promote a discussion about life along and across the color line? This is a discussion that Americans have historically failed to sustain, but archaeology can in some modest way encourage a dialogue about the profound impact of race.

Race in the Near-Westside

Indianapolis' near-Westside declined significantly during the Depression and after World War II, and when federal funding for "slum clearance" programs expanded in the 1950's the community was significantly more over-populated, impoverished, and Black than it had been even 20 years earlier. That memory of a predominately impoverished post-war neighborhood has led many contemporary Indianapolis residents to assume that the area was always an impoverished Black "slum." However, the area actually has had dynamic ethnic and class complexity over a century, and the swath of Indianapolis IUPUI now occupies always had pockets of many different European immigrant groups as well as African Americans and White Indiana-born residents. As in many other contexts, though, Indianapolis' post-war urban transformations often were rationalized by slum caricatures (e.g., Solari 2001). In the midst of Medical Center expansion immediately following World War II, Professor Thurman Rice (1947:164) characterized a 1923 Hospital addition site as "partially a dump and entirely a revolting

Author's version. Final version published as:

Mullins, P.R. (2006). Racializing the commonplace landscape: An archaeology of urban renewal along the color line. World Archaeology, 38(1), 60-71. http://dx.doi.org/ 10.1080/00438240500509884 
slum. Scores of houses must be torn down." Rice painted the neighboring community as an inconvenient obstacle to the Hospital's growth. For instance, Rice (1947:186) remembered that "The housing of the students was a difficult problem in those days [i.e., during World War I]. The plan of putting them in the private rooms was practical only as an expedient and yet the neighborhood was so bad that it was difficult to see how they could be boarded out." Writing just after World War II, Rice (1948:262) observed that "There is still a slum immediately to the south of the City Hospital, but it is constantly being whittled down as the campus expands." Rice skirted the racial makeup of these displaced residents, but in the past he had drawn very clear links between social privilege and biology itself: Rice chaired the Indiana Eugenics Committee, and his 1929 tome Racial Hygiene: A Practical Discussion of Eugenics and Race Culture was a selection for the Eugenics Book Club.

Most of the African Americans who lived in the near-Westside arrived after 1900 during a half-century African-American exodus from the South known as the "Great Migration." Between 1900 and 1920 Indianapolis' African-American population doubled as Southerners fled a depressed farming economy, an absence of jobs, and pervasive racism that legally gave Whites and Blacks different public rights. Attracted by Northern employment, Black Southerners arrived in Indianapolis to find a city with a network of African-American churches, neighborhoods, and a business district with implicit but not codified racism (Brady 1996:1). By 1920, the near-Westside secured its first Black population majority, but some areas would remain home to pockets of European immigrants and Indiana-born Whites into the 1960's. The near-Westside would remain predominately African American, but it was never composed of simply one ethnic

Author's version. Final version published as:

Mullins, P.R. (2006). Racializing the commonplace landscape: An archaeology of urban renewal along the color line. World Archaeology, 38(1), 60-71. http://dx.doi.org/ 10.1080/00438240500509884 
collective, it had complex divisions of affluent and impoverished residents, and it was segregated along racial lines that often varied on a block-by-block basis.

After 1930 the neighborhood declined rapidly, stung first by the Depression, then by World War II migration into the city, and finally by a post-war migration out of the near-Westside as families left the area and the city engineered its rapid displacement. The expansion Thurman Rice envisioned accelerated in the 1950's, when a significant amount of federal funds became available for "slum clearance" projects. In 1956, for instance, a 19-acre tract adjoining the Indiana University Dental School was purchased by the city's Redevelopment Commission using federal funding. The Commission's President called the area "one of the city's most blighted sections," and it clearly was an impoverished neighborhood (Indianapolis Star 1956:1). Like many Northern cities, Indianapolis was a migration point for many especially poor African Americans after World War II, and when they arrived in cities like Indianapolis they were compelled to crowd into marginal locations and modest homes. In 1924 Nelda Adaline Weathers (1924:10) conducted research in these most marginal near-Westside neighborhoods and saw the beginnings of the area's decline, observing that "The greed of landlords, added to the fact that this is one of the oldest parts of Indianapolis, is responsible for the crowding into space properly only large enough for one house, of two, three or even four miserable shacks from which a renumerative income can be gained." Of the 116 families targeted by the 1956 city project, 33 did not have indoor plumbing, 29 had no running water inside, and 63 homes had neither a bath nor shower. A Dental School official eagerly looked forward to new student dormitories and married student housing that could be built on the 1956 acquisition, which was turned over to the University after

Author's version. Final version published as:

Mullins, P.R. (2006). Racializing the commonplace landscape: An archaeology of urban renewal along the color line. World Archaeology, 38(1), 60-71. http://dx.doi.org/ 10.1080/00438240500509884 
repayment of the tract's costs. However, almost all of the property became surface parking lots soon after it was razed, and it remains so today.

The neighborhood's decline punctuated by urban renewal has not found an easy place in public historical memory, and how that period is viewed is key to the archaeological stories we tell about the near-Westside. The post-war neighborhood is the one many people assume was the near-Westside's historical reality, and that perception of the community is often rife with stale slum caricatures. Typical of such caricatures was a State Senator's 2001 bemusement that IUPUI had been built "in the middle of a black ghetto" (Sagamore 2001). Other community members -especially city administrators--prefer to instead minimize the near-Westside's post-war decline and focus on a somewhat romanticized past before urban renewal that revolves around heroic American Dream stories across the color line. Madam C.J. Walker's enormously profitable near-Westside beauty supply firm is the most famous of these enterprises, and Walker's life story is justifiably celebrated as an indication of aspiration's power to defeat racist, class, and patriarchal obstacles. Some of the people who remember the nearWestside instead focus on the history of jazz music along Indiana Avenue. For over a half-century, Indiana Avenue hosted national musicians such as Count Basie and Lionel Hampton and featured nationally known local performers including Wes Montgomery, Jimmy Coe and Freddie Hubbard. This is a critical dimension of Indianapolis' heritage and the community's African-American experience, but jazz histories are often divorced from any systematic analysis of race or culture. Still other observers simply see a dead history: The residents' displacement apparently left neither a significant spatially distinct

Author's version. Final version published as:

Mullins, P.R. (2006). Racializing the commonplace landscape: An archaeology of urban renewal along the color line. World Archaeology, 38(1), 60-71. http://dx.doi.org/ 10.1080/00438240500509884 
neighborhood nor a displaced but self-conscious community, and it clearly left virtually no material traces with which community history might be resurrected.

The Archaeological Evidence of Race

There is no single methodological measure to divine race from any given assemblage, no more than there is any essential ethnic or class identity that reveals itself upon proper archaeological analysis. Instead, assessing how race shapes individual households requires us to contextualize assemblages in ways that ask how particular patterns might reflect, be shaped by, or even be resisting dominant racial ideology and anti-Black racism. In 2002, for instance, we excavated the site of an African-American boarding house on the IUPUI campus. The boarding house was an insubstantial alley structure, and it was three feet away from the wall of a meat-packing operation in the German-American neighbor's backyard. After the turn of the century, once-spacious homes and lots were subdivided to accommodate African Americans arriving in the Great Migration, and the boarding house was built at the very outset of this mass migration, between 1904 and 1910. In 1910 the census-keeper recorded 64year old Hattie Evans as the head of a household that included four lodgers, all of whom were Black, between 25 and 40 years old, and came from Southern families. The household included a seamstress, laundress, servant, janitor, and cook, which was typical of the working-class labors many African-American arrivals found in Indianapolis.

The most illuminating archaeological indication of the household's social position comes from a scatter of straight pins and buttons found directly under the house's floorboards. Ordinary buttons and sewing implements appear to have no connection to

Author's version. Final version published as:

Mullins, P.R. (2006). Racializing the commonplace landscape: An archaeology of urban renewal along the color line. World Archaeology, 38(1), 60-71. http://dx.doi.org/ 10.1080/00438240500509884 
the color line, but in this context they likely reflect the distinctive position of Black women in the early twentieth century. In 1910 Evans was a seamstress, lodger Edna Jones was a laundress, and Bell Thompson was a "servant," probably doing domestic work for a White family. Laundresses and seamstresses often would bring work home, and Thompson was probably doing a vast range of domestic labor that included such tasks. The pins and buttons were located in units directly beneath the house, so it appears that the women were losing these small artifacts through the floorboards. Rather than provide the otherwise mundane indication that the household mended and washed garments, the artifacts instead reflect the service labor Black women were compelled to assume on arriving in Indianapolis.

The prosaic boarding house assemblage does not reveal any clear indications of unique identity, such as a fundamentally distinct African-American culture that is passively reflected in material patterns. Instead, the household's assemblage suggests an utterly dynamic identity that cannot be divorced from the broader structuring influence of racial ideology or the contextual details of life in early twentieth-century Indianapolis. The straight pins reflect how this household was positioned within broader gendered and racialized labor structure. Nevertheless, archaeology does not provide an especially clarion illustration of racial distinction, even though many visitors and archaeologists alike assume the material record will reveal such distinction. Most of our visitors understand the color line as a clear Black/White division, and that facile notion of the color line is undermined by archaeological assemblages that do not portray clear difference. That challenges us to archaeologically paint a picture of how racial privilege

Author's version. Final version published as:

Mullins, P.R. (2006). Racializing the commonplace landscape: An archaeology of urban renewal along the color line. World Archaeology, 38(1), 60-71. http://dx.doi.org/ 10.1080/00438240500509884 
shaped material symbolism, not one in which commodities simply assimilated everybody to implicitly White norms.

Our project has painted racism as a system of privileges that grants particular collectives rights denied to other "partial" members. One of the best material examples of this is foil milk caps excavated from all of our African-American sites. Modest excavations were conducted at IUPUI before my project began in 1999, and in those artifacts a circa 1935 assemblage included several foil milk bottle closures. These had been consigned to storage, since their only story appeared to be the rather insipid indication that these households drank milk. Not long afterward, though, an AfricanAmerican elder related a story about Riverside Amusement Park, a prominent local amusement park modeled on Coney Island. The Park was among Indianapolis' central social spaces for over 60 years, hosting proms, weddings, and innumerable weekend gatherings around a fleet of roller coasters and thrill rides. However, the Park restricted access to Whites; even in openly xenophobic Indianapolis, it was unusual to find such codified White exclusivity. Only once each year did the Park admit African Americans for its "Colored Frolic" day, and to gain admission Black patrons would bring a milk cap: Consequently, this was known as "Milk Cap Day" to African Americans. This story invested the milk caps with a quite powerful story about life along and across the color line.

The material forms race might take in any given assemblage are contextually very distinctive. In 2004, for instance, we excavated the former home of Joseph and Zella Ward, a circa 1892 residence in the Ransom Place neighborhood. Like his neighbors in the 800 block of California Street, Dr. Joseph Ward was a person of status.

Author's version. Final version published as:

Mullins, P.R. (2006). Racializing the commonplace landscape: An archaeology of urban renewal along the color line. World Archaeology, 38(1), 60-71. http://dx.doi.org/ 10.1080/00438240500509884 
Ward befriended CJ Walker when she arrived in Indianapolis in 1910, and Walker's firs customers were served in the Wards' living room (Bundles 2001). Ward served as Walker's attending physician until her death in 1919. He eventually ran the city's only Black hospital, was the highest-ranking African-American Army officer in World War I, and from 1924 to 1936 served as the Administrator of the Tuskegee Veteran's Hospital. The other residents of the home after 1916 were similarly well-situated African Americans, including the head of the local Colored YMCA, the Pastor of Bethel AME Church, and an entrepreneur who ran a prominent dry cleaning business.

This string of reasonably affluent success stories left an unusually sparse material assemblage that does not suggest particular wealth or status. The most distinctive dimension of the assemblage was the home's extensively modified lawn. Decorative laid sidewalks, dense flower and plant beds, and a wrap-around porch bordering floor-to-ceiling windows paint a picture of a stereotypical bourgeois yardscape. The almost complete absence of artifacts in the yard indicates it was exceptionally wellmanicured, and many of the neighbors' lawns also were neatly fenced spaces with ornamental features like elaborate fish ponds. The effort to make genteel urban homes a material "retreat" from city life was common in American cities, so in many ways this is not at all surprising. Indianapolis resident Walter Hendrickson (1983:61) remembered such a World War I-era neighborhood, indicating that his family "and the other proud owners of these new houses planted Norway maples in our front yards, and put in spirea and barberry shrubbery as foundation planting around the front porches. The backyards were devoted to flower beds, fruit trees, and fruit-bearing shrubs." However, finding such a neighborhood peopled by well-educated, affluent, and utterly genteel African

Author's version. Final version published as:

Mullins, P.R. (2006). Racializing the commonplace landscape: An archaeology of urban renewal along the color line. World Archaeology, 38(1), 60-71. http://dx.doi.org/ 10.1080/00438240500509884 
Americans posed a stark contrast to the assumption that such neighborhoods were exclusively White.

Even marginalized African-American contexts counter the caricature of Black slums painted in much popular discussion. In 2001, for example, we excavated ten homes in a single block that had become densely populated during the Depression. In the midst of the block one landlord even built a two-story outhouse to save space and serve a four-apartment rental. Yet like the Ward yard, archaeology revealed decorative brick sidewalks fanning throughout much of the block, with the faint soil stains of flower beds and gardens dotting the backyard. The African-American near-Westside's widespread embrace of genteel landscape ideology indicated that to be genteel and Black were not exclusive identities, so these yards dealt a blow to caricatures of AfricanAmerican materialism (cf. Mullins 1999:18).

\section{Race and Privilege}

The milk caps and straight pins tell a story about privileges across the color line, and like the IUPUI parking lots it is not a self-evident story. The process of inferring meaning from things is never utterly crystalline, so the question really is exactly what sorts of discourses do we want archaeology to produce? An archaeology of race should produce a public discussion about race, class, and cultural differences that might otherwise not happen. For contemporary African-American descendant communities and displaced near-Westside residents, the apparent and actual invisibility of their community heritage is especially distressing, so much of what archaeology can do is attempt to bring that heritage into public space. Milk caps and parking lots should tell us

Author's version. Final version published as:

Mullins, P.R. (2006). Racializing the commonplace landscape: An archaeology of urban renewal along the color line. World Archaeology, 38(1), 60-71. http://dx.doi.org/ 10.1080/00438240500509884 
something about how race shaped citizen privileges and everyday life along the color line, and they do this very well because we typically ignore these dimensions of such objects and spaces. Archaeological sites and commonplace things provide particularly powerful ways to initiate conversations about the unrecognized historical basis for contemporary privileges. The history of milk caps is clearly linked to White privilege in the minds of many African Americans, and the IUPUI parking lots might just as easily be called products of anti-Black racism, but neither is seen as such. The fact that the racist exclusion at Riverside Park or the near-Westside's racial displacement are now unrecognized less than a half-century afterwards is itself a powerful statement of how racism can be made to seem appropriate or at least utterly distanced from the present. An archaeology of race and the color line can illuminate how race shapes even the most everyday things and commonplace rights, pushing us toward a long-evaded discussion about the profound power race has had on all citizens' rights and objects as commonplace as parking lots and milk caps.

Author's version. Final version published as:

Mullins, P.R. (2006). Racializing the commonplace landscape: An archaeology of urban renewal along the color line. World Archaeology, 38(1), 60-71. http://dx.doi.org/ 10.1080/00438240500509884 


\section{Acknowledgements}

Thanks to Greg Mobley and the IUPUI University Archives staff for sharing their research on campus parking. Daisy Borel, Chris Glidden, and my colleagues in the IUPUI Anthropology Department all shaped various pieces of this paper. None of them bear any responsibility for its shortcomings.

Author's version. Final version published as:

Mullins, P.R. (2006). Racializing the commonplace landscape: An archaeology of urban renewal along the color line. World Archaeology, 38(1), 60-71. http://dx.doi.org/ 10.1080/00438240500509884 
Bibliography

Babson, D.W. 1990 The Archaeology of Racism and Ethnicity on Southern plantations. Historical Archaeology 24(4):20-28.

Brady, C.M. 1996. The Transformation of a Neighborhood: Ransom Place Historic District, 1900-1920. Thesis submitted to Department of History, Indiana UniversityPurdue University, Indianapolis.

Bundles, A. 2001 On Her Own Ground: The Life and Times of Madam C.J. Walker. New York: Scribner.

Cohen, L. 2003 A Consumers' Republic: The Politics of Mass Consumption in Postwar America. New York: Knopf.

Davidson, J.M. 2004. Mediating Race and Class through the Death Experience: Power Relations and Resistance Strategies of an African-American Community, Dallas Texas (1869-1907). Dissertation submitted to the Department of Anthropology, University of Texas, Austin.

Epperson, T.W. 1990 Race and the Disciplines of the Plantation. Historical Archaeology 24(4):29-39.

Epperson, T.W., 2004 Critical Race Theory and the Archaeology of the African Diaspora. Historical Archaeology 38(1):101-108.

Hendrickson, W.B. 1983 The Indiana Years, 1903-1941. Indiana Historical Society, Indianapolis.

Indianapolis Star. 1956. Medical Center to Build on Slum Cleared Acres. October 4:1, 9.

Moore, L.J. 1991 Citizen Klansmen: The Ku Klux Klan in Indiana, 1921-1928 Chapel Hill: University of North Carolina Press.

Mullins, P.R. 1999. Race and Affluence: An Archaeology of African America and Consumer Culture. New York: Kluwer.

Onomatopoeia. 1970. Letter to the editor: Parking to be adequate on new Campus? April 27:4.

Orser, C.E., Jr. 2004 Race and Practice in Archaeological Interpretation. Philadelphia: University of Pennsylvania Press.

Author's version. Final version published as:

Mullins, P.R. (2006). Racializing the commonplace landscape: An archaeology of urban renewal along the color line. World Archaeology, 38(1), 60-71. http://dx.doi.org/ 10.1080/00438240500509884 
Paynter, R. 1990. Afro-Americans in the Massachusetts Historical Landscape. In The Politics of the Past (eds. P. Gathercole and D. Lowenthal). London: Unwin Hyman, pp. 49-62.

Rice, T.B. 1947. One Hundred Years of Medicine: Indianapolis, 1820-1920, Chapters 1-12. Monthly Bulletin of the Indiana State Board of Health.

Rice, T.B. 1948. One Hundred Years of Medicine: Indianapolis, 1820-1920, Chapters 13-23. Monthly Bulletin of the Indiana State Board of Health.

Roberts, B. 1967. Neighborhood to Vanish Soon. Indianapolis News July 11:38.

Sagamore 2001. IUPUI in Jeopardy. January 22:7.

Roediger, D.R. 1991 The Wages of Whiteness: Race and the making of the America Working Class. Verso, New York.

Solari, E. 2001 The Making of an Archaeological Site and the Unmaking of a Community in West Oakland, California. In The Archaeology of Urban Landscapes: Explorations in Slumland, (eds. A. Mayne and T. Murray). Cambridge: Cambirdge University press, pp.22-38.

Weathers, N.A. 1924. How the Negro Lives in Indianapolis. Thesis submitted to Social Service Department, Indiana University.

Author's version. Final version published as:

Mullins, P.R. (2006). Racializing the commonplace landscape: An archaeology of urban renewal along the color line. World Archaeology, 38(1), 60-71. http://dx.doi.org/ 10.1080/00438240500509884 
FIGURE 1: The White River cuts through this 1958 picture from the south (the left), with the Indiana University Medical Campus in the center of the picture. The remaining houses in the foreground and to the right of the medical Center buildings would virtually all be razed in the next 25 years (Photograph courtesy IUPUI University Library Special Collections and Archives).

FIGURE 2: In 1922, construction began on a new Indiana University Hospital while neighbors continue to farm cabbage in the foreground (Photograph courtesy IUPUI University Library Special Collections and Archives).

FIGURE 3: The two Polk's Dairy milk caps at the top were recovered archaeologically from a site in the Ransom Place neighborhood. The cap at bottom is typical of what such "alumaseal" closure systems originally looked like when they were used in the 1930's (Photograph courtesy of author).

Author's version. Final version published as:

Mullins, P.R. (2006). Racializing the commonplace landscape: An archaeology of urban renewal along the color line. World Archaeology, 38(1), 60-71. http://dx.doi.org/ 10.1080/00438240500509884 